\title{
The Financial Policy of Outstripping Growth under Conditions of Russian Regions' Social and Economic Development's Asymmetry
}

\author{
Marina Sergeeva Tolstel \\ Lomonosov Moscow State University, \\ Faculty of Economics \\ Moscow, Russia \\ marina-tolstel@yandex.ru
}

\author{
Rustam Alievich Yalmaev \\ Chechen State University \\ Faculty of public administration \\ Grozny, Russia \\ imamat@list.ru
}

\author{
Maxim Petrovich Pridachuk \\ Volgograd branch of the Russian Presidential Academy of National Economy and Public Administration \\ Faculty of Economics \\ Volgograd, Russia \\ pridachuk@yandex.ru
}

\begin{abstract}
Authors have identified the asymmetry of the Russian regions socio-economic development, identified key signs of uneven socio-economic development in space, as well as its factors. The article substantiates the need to transform modern financial policy, which is a factor in further deepening the unevenness and growth of territories differentiation according to the level of social and economic development. Within the framework of regional economic science, the search for effective mechanisms, scientifically based principles and approaches to overcome territorial contrasts and disproportions in the socioeconomic development of the regions through the implementation, including the financial policy of outstripping growth, is becoming especially important. The authors clarified the notion of "financial policy of outstripping growth", identified its main financial instruments at the national and regional levels aimed at achieving sustainable economic growth in the Russian regions, smoothing disproportions in territorial development.
\end{abstract}

Keywords- financial policy, region, sustainable growth, the asymmetry of social and economic development, financial instruments

\section{INTRODUCTION}

The asymmetry of the territories socio-economic development, as the analysis has shown, is found in many states. However, this problem is most acute for countries that have a significant state territory. In this case, the unevenness that arises in the formation of a single economic space of the country is unavoidable, since they are natural and conditioned by the objective properties of space-dimensionality and heterogeneity.

The asymmetry of the territories socio-economic development is a phenomenon that has as its basis the inequality of resource support for individual territories, limiting the possibilities for further development and increment of the resource base, which has a mechanism for the reproduction of itself and is expressed in deepening the differentiation of territories according to the level of socioeconomic development.

In this regard, within the regional economic science, the search for effective mechanisms, scientifically based principles and approaches to overcome territorial contrasts and imbalances in the socio-economic development of regions.

\section{MATERIALS AND METHODS (MODEL)}

In the economic literature different approaches to the definition of the "asymmetry of socio-economic development" are used, but the functional-content aspect of this category is the existence of differences in the levels of territories development, caused by the inequality of their resource supply, structural shifts in the economy, limited financial support, leading to deepen the differentiation of territories [1].

As the analysis has shown, the asymmetry of the Russian territories socio-economic development is expressed in the difference in the growth rates of three types of interrelated indicators: the volumes and quality of economic resources used in the territories, the volumes of goods and services produced, and the volume of goods purchased by economic entities located on them.

Analysis of the Rosstat data allows us to conclude that there are significant differences in the rates of socioeconomic development both between the federal districts of the Russian Federation and within them - between constituent entities of 
the Russian Federation, and within the constituent entities of the Russian Federation - between the territories belonging to them.

Differences in the growth rates of resource levels between federal districts are reflected in Table 1.

TABLE I. RELATIONSHIP BETWEEN GROWTH, CENTRAL FEDERAL DISTRICT $=1,2016$

\begin{tabular}{|c|c|c|c|c|}
\hline \multirow{2}{*}{$\begin{array}{c}\text { Federal } \\
\text { District }\end{array}$} & \multicolumn{4}{|c|}{$\begin{array}{c}\text { The ratio of the growth rates of the indicator to } \\
\text { the growth rate of the Central Federal District } \\
\text { indicator }\end{array}$} \\
\cline { 2 - 5 } & $\begin{array}{c}\text { Number of } \\
\text { Employed }\end{array}$ & $\begin{array}{c}\text { The } \\
\text { Volume } \\
\text { of } \\
\text { Investme } \\
\text { nt }\end{array}$ & $\begin{array}{c}\text { Number of } \\
\text { Organizati } \\
\text { ons }\end{array}$ & $\begin{array}{c}\text { Number of } \\
\text { Individual } \\
\text { Entrepren } \\
\text { eurs }\end{array}$ \\
\hline Cental & 1,00 & 1,00 & 1,00 & 1,00 \\
\hline Northwestern & 0,35 & 0,44 & 0,35 & 0,36 \\
\hline Southern & 0,37 & 0,29 & 0,21 & 0,58 \\
\hline North & 0,20 & 0,13 & 0,08 & 0,22 \\
\hline Caucasian & 0,71 & 0,64 & 0,46 & 0,70 \\
\hline Volga & 0,30 & 0,72 & 0,22 & 0,33 \\
\hline Siberian & 0,44 & 0,37 & 0,30 & 0,46 \\
\hline Far Eastern & 0,15 & 0,26 & 0,11 & 0,19 \\
\hline
\end{tabular}

Source: calculated by the authors according to Rosstat [2].

Asymmetry of territories development takes place and in federal districts - between subjects of the Russian Federation. It is especially evident in the Central Federal District. Here the main center for the attraction of resources is Moscow, which outstripped substantially all the territories of the District, as well as Russia as a whole, in terms of GRP per capita growth rates. In the Northwest Federal District, the role of the center of resources attraction is played by St. Petersburg.

In the Southern and North-Caucasian Federal District, there are no clearly defined centers of resources attraction, although a number of Russian regions developed faster than others. In the Volga Federal District, the Republic of Tatarstan is the clear center of resource attraction in terms of growth in the number of enterprises and volumes of goods and services.

In the Ural Federal District, the role of the center for the resources attraction was performed by the Tyumen region thanks to the country's largest oil and gas reserves. In the Siberian Federal District, the centers of resources attraction were the Tomsk and Novosibirsk regions, although the Krasnoyarsk region was the leader in per capita GRP growth rates, with considerable natural resources and industrial potential.

In the Far Eastern Federal District, the distribution of resources by Russians regions over the past 10 years has not undergone any significant changes, except for a significant decrease in the share of the Jewish Autonomous District and the Magadan region taken together of resources.

Thus, within each federal district, as a rule, processes similar to those observed at the level of the country as a whole took place: from one to three constituent entities of the Russian Federation, which played the role of a center for the resources attraction. The difference in the per capita GRP level between the constituent entities of the Russian regions increased, while in the average monetary salary and average cash incomes, on the contrary, they declined.

Therefore, the increase in the coefficient of funds and the Gini index over the past decade indicates an increase in socioeconomic inequality not between the regions of the Russian Federation, but within the latter.

The capitals of the Russian regions attracted resources for the reason that they significantly exceeded the periphery in terms of the demand volume for goods and services, they make it easier to find work for the inhabitants of the periphery. The movement of resources from the periphery to the center can strengthen itself: the transfer of resources to the center reduces entrepreneurial activity on the periphery and causes a further outflow of resources from the periphery. The inflow of resources to metropolitan cities occurs even with the reduction in industrial production in them - due to the development of infrastructure, trade and services. In a number of cases, metropolitan cities are turning into shopping centers in which industry plays an increasingly less important role, and they are increasingly trading in goods imported from other territories.

Based on the material studied, it is possible to identify signs of asymmetry in socio-economic development in space.

First, the basis of uneven development is initially unequal resource support for individual economic entities (in our understanding of individual territories within the region). Moreover, inequality is expressed not only in the possession of resources in different numbers but also in different quality, as well as in structural resource imbalances (for example, accessibility on the territory of labor, land, capital, entrepreneurial abilities). This leads to a differentiation of opportunities and the potential for independent development among a set of these regions.

Secondly, unequal resource provision, which is the basis for socio-economic development, is the reason for the different rates of income growth of individual economic entities (individual territories), which leads to the subsequent unequal increase (accumulation) of the existing resource base, both in absolute and in relative expression.

Thirdly, the unequal increment of resource bases indicates further deepening of unevenness and growth of economic entities differentiation (in our understanding of territories) in terms of socio-economic development.

Thus, there is a certain circuit of constant reproduction and deepening of social and economic development's asymmetry in space (between separate territories).

But it is worth noting that there are special cases when under the influence of strong external factors (for example, external investments, direct state participation, a sharp change in the market situation, etc.), some economic entities are knocked out from the influence of this pattern, but in a circle other persons it continues to operate. 
One of the factors of asymmetric development of the territories is insufficiently effective financial policy, not aimed at creating and supporting the institutional and organizational structure and infrastructure for the development of human capital, business, and reproduction of the resource base.

\section{RESULTS AND DISCUSSION}

\section{A. The financial policy of outstripping growth and its main tools}

To overcome the negative consequences of territorial development, it is first necessary to introduce drastic changes in the financial policy of the state. It should concentrate not on attempts to mitigate the consequences of territories uneven development through redistribution of budgetary funds, but on systematic influence on the location of productive forces throughout the country. A long-term state program for the allocation of productive forces is needed, ensuring both the overcoming of the raw material orientation of economic development and the integrated development of all regions, including the revival of production and the restoration of infrastructure in them.

One of the modern problems of attracting investments at the regional level is the constant rivalry between the regions, which consists in dragging potential investors from each other, whereas it is necessary to be included in the global competition for investments, increasing the competitiveness of the Russian Federation as a whole. To achieve this goal, it is necessary to change strategies and competencies not only in regional administrations, but also at the federal level [3].

In our opinion, it is important to shift to the financial policy of outstripping growth aimed at achieving sustainable growth rates of regions and the country as a whole with the help of available financial instruments, the main of which are fiscal, monetary and investment (Figure 1).

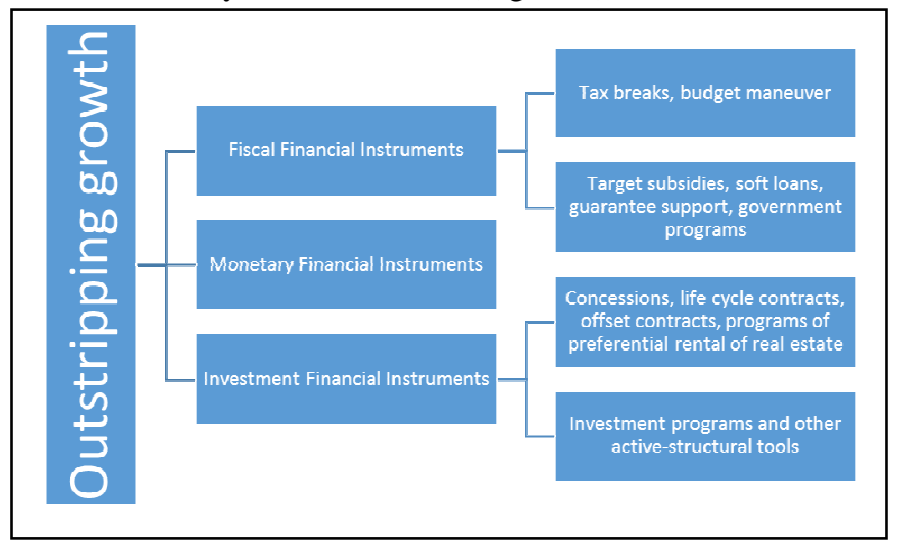

Fig. 1. Financial instruments of outstripping growth.

As the analysis shows, at the federal level, monetary and fiscal instruments are priority, while at the regional level, investment instruments are priority. In modern conditions, the factors of leadership in attracting investments are not so much the available minerals and other resources in the region, as well as favorable conditions for rational use of resources and effective fund-raising. With this in mind, the regions need to identify or create their own competitive advantages, and develop those promising industries that will enhance their competitiveness.

\section{B. Results of the financial instruments use effectiveness analysis (on the example of Moscow)}

An analysis of the investment climate in the constituent entities of the Russian Federation, which is prepared by the Agency for Strategic Initiatives, showed that despite the strengthening of the regions positions, Moscow moved from 10th to 3rd place for the year [4]. Thanks to the consistent work of the Moscow government to create attractive conditions for life and business, the capital accounts for about $12 \%$ of the total Russian investment in fixed assets and half of Russia's direct foreign investment. According to the Federal State Statistics Service, for three quarters of 2017 the volume of investments in fixed assets in Moscow amounted to 1.1 trillion rubles, which is $20 \%$ more in real terms than in the same period in 2016. Over seven years, the volume of investments in fixed assets increased by almost $70 \%$ in comparable prices to the level of 2010 [5].

In Moscow, tax incentives are provided for management companies and residents of technopolis, technology parks and industrial parks for profit tax, property tax and land tax. For residents of technopolis, technology parks and industrial parks, a $0 \%$ rate is set for property tax. For management organizations of technoparks, technopolis, $0 \%$ property tax rates, $0.7 \%$ of the tax amount calculated for the occupied land plot, are set for land tax. For managing organizations of industrial parks for property tax $-50 \%$ of the amount of tax calculated in respect of the property complex of an industrial park, for land tax - $20 \%$ of the amount of tax calculated in respect of the occupied land. Privileges are granted for a period of 10 years from the moment of status assignment as resident or management company of a technopolis, technopark or industrial park. The tax rate for residents of technopolis, technology parks and industrial parks is set at $13.5 \%$. In Moscow, work is annually carried out to assess the effectiveness of tax benefits established by city legislation. Based on the results of the tax benefits assessment, a decision is made to abolish or correct them.

In Moscow, the following measures of financial support are provided for certain categories of enterprises and activities: subsidizing of leasing payments: up to 100 million rubles for one enterprise (25\% of costs); subsidizing the receipt of certificates of international standards: up to 1 million rubles ( $40 \%$ of total costs); reimbursement of costs for loans to management companies of technology parks (up to 100 million rubles, interest rate payment at the rate of refinancing rate) and technopolises (up to 300 million rubles, interest rate payment at the rate of refinancing rate); subsidizing the cost of placing securities for small innovative companies (up to 5 million rubles $2 / 3$ of costs); subsidizing the costs of equipping and functioning of innovation centers for youth innovation creativity centers (up to 10 million rubles, $60 \%$ of costs); subsidies for start-up entrepreneurs up to 500 thousand rubles; subsidies for reimbursement of interest on a loan for small manufacturing enterprises and individual entrepreneurs (up to 5 million rubles); subsidies to 
organizations that carry out activities in the field of innovation in order to reimburse a part of the costs aimed at organizing the production of new products: the acquisition of rights to use the results of intellectual activity, the preparation and implementation of intellectual activity's exclusive rights registration, to pay under contracts for accession to engineering networks and facilities, to confirm compliance, to conduct research and development work for employees the organization associated with the development of new technological equipment; subsidies to organizations forming an innovative infrastructure in the city of Moscow, in order to recover part of the costs associated with the creation, development and modernization of their material and technical base. As for tax benefits, a periodic evaluation of their effectiveness is provided for grants and an adjustment to the results of such an assessment.

Moscow was one of the first to develop public-private partnerships (PPPs). In 2013-2017 years, contracts were concluded on PPP projects for 701.5 billion rubles. Priority areas are the development of transport, social infrastructure, education, health services, and housing and communal services. Various forms are used - concessions, life cycle contracts, offset agreements [6].

According to the Investment strategy of Moscow until 2025, the locomotive of the economy should be high-tech production. Investment programs are implemented for both existing and new projects.

Depending on the economic parameters (revenue, payroll, average wages, investments per 1 ha of occupied plots, etc.), enterprises can claim for statuses - industrial park, industrial complex, industrial park, which will not only reduce the regional tax burden by $17-25 \%$, but also receive a number of benefits (reduced rates of rent, preferential payments, etc.). The right to receive support measures for this reason has already been confirmed by 71 companies (36 of them are industrial complexes, 32 technoparks, and 3 anchor residents of the technopark). The dynamics of the development of the program of technoparks in Moscow is presented in Figure 2.

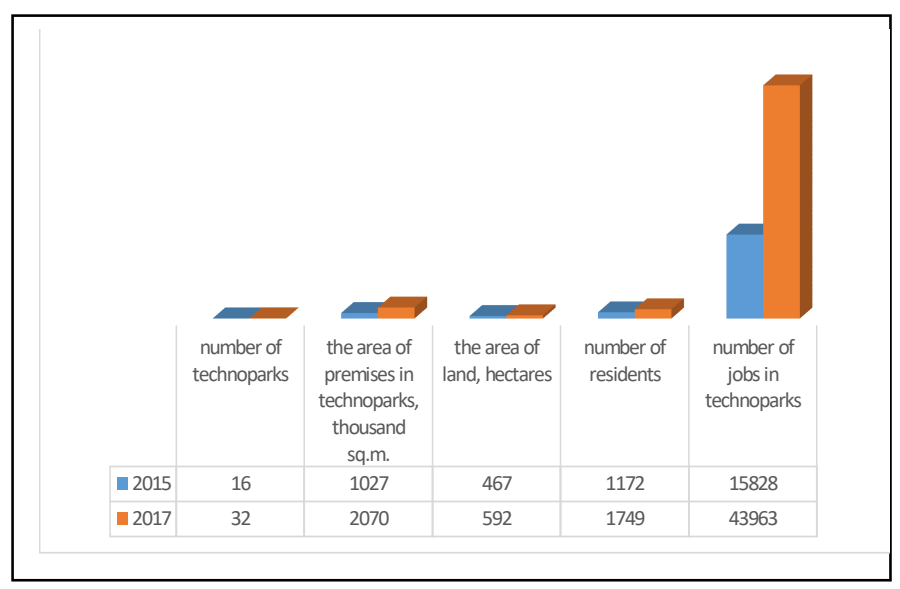

Fig. 2. Dynamics of technoparks program development in Moscow [7].

A wide range of budget-investment financial instruments is available to the new investment project, which received the status of priority, such as zeroing of tax payments, subsidies for reimbursement of expenses for technical connection to engineering networks. Regarding the residents of the special economic zone Technopolis Moscow, there is additionally a free customs zone regime that allows the import of equipment and materials without payment of value added tax and import duties.

Among the drivers of development is Moscow's targeted investment program. Due to the allocation of funds for the development of construction and reconstruction of urban infrastructure, a multiplicative effect is achieved.

\section{Financial mechanism of the region economy' outstripping development}

The complexity and multidimensional nature of the tasks that regional authorities need to address in the context of territories asymmetric socio-economic development of require a correct consideration of the regional development processes, changes in methodological approaches to the construction of a financing system that corresponds to the current conditions of regional functioning.

On the basis of the analysis, the authors determine the financial mechanism for the outstripping development of the regional economy as a system for regulating the formation, distribution and use of territories external and internal financial resources aimed at achieving high growth rates in the medium and long term due to qualitative changes in the structure of the economy that can be achieved, using primarily investment financial instruments and fiscal-budgetary ones (Figure 3).

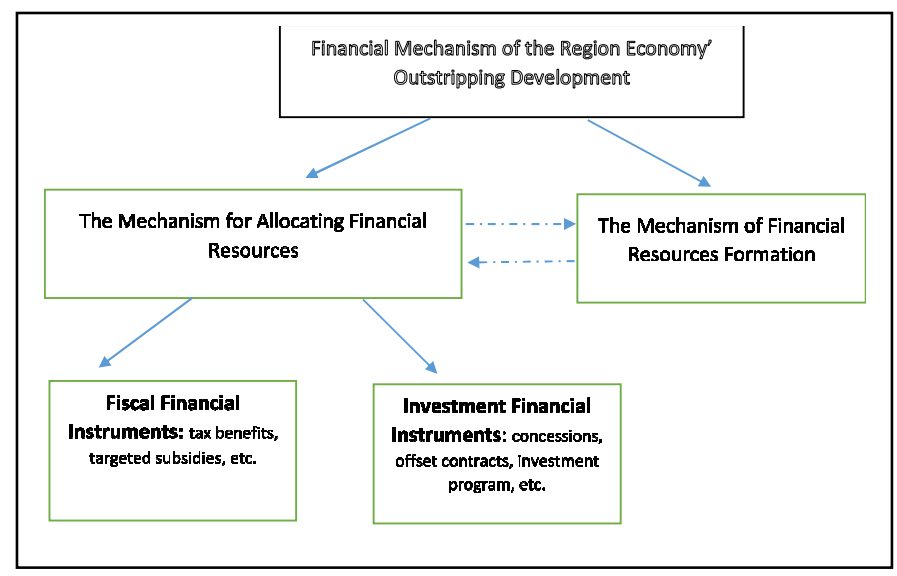

Fig. 3. Financial mechanism of the region economy' outstripping development.

Thus, the development of a mechanism for implementing the financial policy of the region requires an assessment of available financial sources, for this purpose it is necessary to analyze the consolidated financial resources of the region, to consider in detail options for financing from the regional budget, attracting domestic and foreign investments, using higher-level budgets, loans and etc. The next stage, in our opinion, should be the purposeful activity of regional authorities aimed at creating conditions for attracting and retaining financial resources in the region. Thus, there is a 
need to search for new financing instruments, which under current conditions should be mainly oriented towards the domestic financial market and targeted funds, including budget funds.

In modern conditions, a number of regions have problems in attracting investments, which causes an insufficient flow of investment capital into the region. In this regard, the main objectives of the financial policy of outstripping growth should be the creation of a favorable investment climate and the formation of an effective system for attracting investment and supporting investment projects in the region.

Therefore, for example, the leadership of the Volgograd region is attempting to increase the investment potential of the region. To increase the volume of investment, interested stakeholders are provided with state support in the implementation of investment projects in accordance with the current legislation and favorable conditions are created for the implementation of investment activities. The system is constantly improving the system of providing state support to investors, measures are being taken to provide them with preferences and benefits when implementing investment projects in priority areas of development.

The investment policy of the Volgograd region is also focused on improving administrative procedures and reducing the costs of providing public services with regard to simplifying the provision of permits for investors and reducing the time frame, switching to the provision of public services in electronic form, conducting public discussion and assessing the regulatory impact of draft and expertise of the current regulatory legal acts of the region.

Recommendations obtained based on SWOT-analysis of investment policy and investment climate in a number of regions of the Russian Federation, predetermine:

creation of favorable conditions for the implementation of investment projects in the priority areas of the region's economic development;

assistance in the formation of new investment sites and development of existing (development territories, territorial growth points and special economic zones), including jointly with other regions;

development of related infrastructure (engineering and transport and logistics infrastructure);

expansion of partnership relations with foreign countries in order to create conditions for increasing the volume of exports of the region's products and attracting foreign investment;

interaction of local governments with federal executive bodies for the timely use of new federal instruments to support investment projects;

development of subcontracting interactions with large business and small and medium business entities in the most developed sectors of the region's economic development;

elimination of administrative barriers and minimization of corruption risks; implementation of measures to attract investment in the field of high technology and high production and technology [8].

As the analysis of Moscow's experience has shown, the transition to faster growth in the region's economy can be achieved through the use of investment financial instruments in conjunction with fiscal and budgetary funds by creating an effective system for attracting investments, increasing their volume for projects in the priority sectors of the region's economy and creating an associated infrastructure, providing investment attractiveness of the region, as well as supporting investment projects.

\section{CONCLUSION}

As the analysis has shown, under modern conditions, the asymmetry of the Russian regions socio-economic development is intensifying, which causes difficulties in the transition to a strategy of outstripping growth. The authors substantiate the need to transform modern financial policy, which is a factor in further deepening the unevenness and growth of territories differentiation according to the level of social and economic development. Within the framework of regional economic science, the search for effective mechanisms, scientifically based principles and approaches to overcome territorial contrasts and disproportions in the regions socio-economic development through the implementation, including the financial policy of outstripping growth, is becoming especially important. The authors clarified the notion of "financial policy of outstripping growth", identified its main financial instruments at the national and regional levels aimed at achieving a stable high growth rate of the Russian regions economy. The analysis of the Moscow best practices on the transition to outstripping economic growth suggests the use of investment financial instruments in conjunction with fiscal and budgetary funds by creating an effective system for attracting investments, increasing their volume for projects in the priority sectors of the region economy and creating an associated infrastructure that provides investment attractiveness of the region, as well as accompanying investment projects.

\section{References}

[1] M. Tolstel, R. Yalmaev. Financial support of small and medium-sized business under the conditions of Russian regions social and economic development's asymmetry [Finansovaya podderzhka malogo i srednego predprinimatel'stva v usloviyakh asimmetrii sotsial'no-ekonomicheskogo razvitiya rossiiskikh regionov] Grozniy, 2018. - pp. 32-37

[2] Federal State Statistics Service (Rosstat). Regions of Russia: socioeconomic indicators. [online]. - Available at: http://www.gks.ru/free_doc/doc_2017/region/reg-pok17.pdf

[3] E. V. Gribova. Investment climate in Russia: inflow and outflow of foreign capital [Investitsionnyi klimat $\mathrm{v}$ Rossii: pritok $\mathrm{i}$ ottok inostrannogo kapitala]/ E. V. Gribova // Economic Analysis: Theory and Practice [Ekonomicheskii analiz: teoriya i praktika]. - 2013. - № 12. pp. 27-37.

[4] Agency for Strategic Initiatives. National investment rating of the constituent entities of the Russian Federation. [online]. - Available at: http://asi.ru/investclimate/rating/.

[5] Federal State Statistics Service (Rosstat). Regions of Russia: socioeconomic indicators. [online]. - Available at: http://www.gks.ru/free_doc/doc_2017/region/reg-pok17.pdf. 
[6] The investment strategy of the city of Moscow for the period until 2025. [online]. Available

https://investmoscow.ru/media/234941/\%D0\%98\%D0\%BD\%D0\%B2\% D0\%B5\%D1\%81\%D1\%82\%D0\%B8\%D1\%86\%D0\%B8\%D0\%BE\%D0 $\% \mathrm{BD} \% \mathrm{D} 0 \% \mathrm{BD} \% \mathrm{D} 0 \% \mathrm{~B} 0 \% \mathrm{D} 1 \% 8 \mathrm{~F}-$

\%D1\%81\%D1\%82\%D1\%80\%D0\%B0\%D1\%82\%D0\%B5\%D0\%B3\% D0\%B8\%D1\%8F-

$\% \mathrm{D} 0 \% 9 \mathrm{C} \% \mathrm{D} 0 \% \mathrm{BE} \% \mathrm{D} 1 \% 81 \% \mathrm{D} 0 \% \mathrm{BA} \% \mathrm{D} 0 \% \mathrm{~B} 2 \% \mathrm{D} 1 \% 8 \mathrm{~B}-$

\%D0\%B4\%D0\%BE-2025-\%D0\%B3\%D0\%BE\%D0\%B4\%D0\%B0.pdf
[7] Technoparks and technopolises of Moscow [online]. - Available at: https://investmoscow.ru/industry-and-innovation/activetechparks/techparks/techparkareas/

[8] M.S. Tolstel, Z.A. Akhmedova. Investment attractiveness of the Southern Federal District regions: current trends, ways to improve [Investitsionnaya privlekatel'nost' regionov YuFO: sovremennye trendy, puti povysheniya]// Regional economy. South of Russia [Regional'naya ekonomika. Yug Rossii]. - 2017. - № 3 (17) . pp. 101-110. 